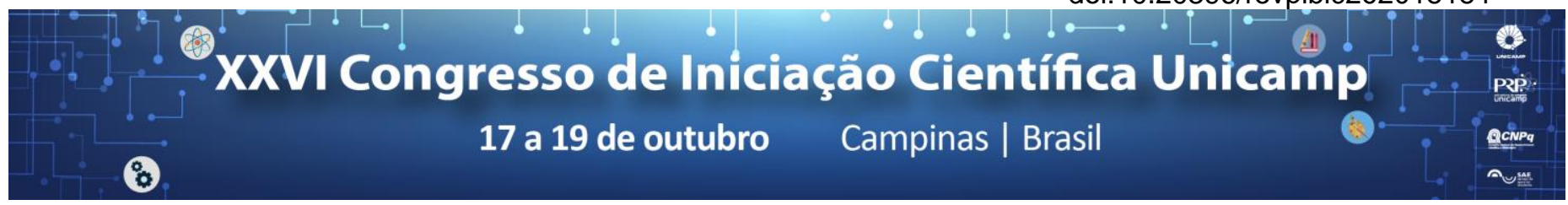

\title{
André Lhote e a obra "Interior com figuras femininas", de 1936
}

\author{
Bárbara D. Gonçalves, Gabriel Ferreira Zacarias
}

\section{Resumo}

André Lhote (França, 1885 - 1962) foi escultor, pintor, crítico e educador. Preocupado não apenas com o ato de pintar, mas também com as teorias que o pintar envolvia, Lhote realizou ampla produção escrita, incluindo textos críticos na revista Nouvelle Revue Française - da qual foi co-fundador -, livros sobre aspectos da produção das vanguardas e tratados sobre pintura, paisagem e figura. Ele está presente no acervo do Museu de Arte de São Paulo Assis Chateaubriand (MASP) com duas obras que expõe dois momentos distintos de seu percurso como artista. O presente projeto de pesquisa propõe o estudo específico de um desses quadros, Interior com figuras femininas, de 1936, acerca de seus aspectos temático, pictórico e contextual e em face da escassez de trabalhos em português sobre o artista e sobre esta pintura. A partir do exercício de análise da obra em conjunto com a seleção e a leitura de bibliografia e de parte da obra crítica de Lhote, será possível desvendar características e tendências de sua pintura, tanto nas interlocuções que estabelece juntamente aos movimentos artísticos com os quais dialogou quanto na originalidade de seus trabalhos.

\section{Palavras-chave:}

Arte Moderna; França; André Lhote.

\section{Introdução}

O envolvimento de André Lhote com o Cubismo se deu a partir de 1911, estendendo-se para a Section d'Or em 1912 e para o Cubismo Sintético em 1917. Sobre esse tema e período, é relevante a diversidade de referências que integrou o movimento cubista. O chamado grupo cubista "de Salão", do qual fez parte Lhote, mobilizava temas reconhecíveis através de uma forma plástica que captava a atenção e, assim, dirigia-se a um público amplo. Ambos, porém, "de Salão" e "de Galeria", de maneiras diferentes, revelam como as vanguardas estavam fortemente assentadas na dinâmica política, social e econômica, nesse caso, da Paris do início do século XX. Lhote seguiu sua carreira professando cursos e conferências e realizando, além das obras pictóricas, vasta produção escrita, incluindo tratados e teorizações sobre pintura e, por 23 anos, textos críticos na revista Nouvelle Revue Française. A pesquisa parte da leitura de tais escritos em conjunto com a análise de "Interior com figuras femininas", buscando compreendê-lo no que concerne à sua interlocução com a arte europeia da primeira metade do século $X X$ e com os percursos da produção pictórica e crítica do próprio artista.

\section{Resultados e Discussão}

A pesquisa está organizada nas quatro etapas metodológicas seguintes: levantamento e leitura de bibliografia geral sobre teoria de história da arte e arte moderna e específica acerca de André Lhote e de seu lugar dentro dos movimentos artísticos dos quais participou e com os quais dialogou; análise formal de fonte, na qual são focalizados os aspectos pictóricos, formais e temáticos do quadro; contextualização do quadro dentro dos processos artísticos de seu período e do próprio pensamento de Lhote como crítico e tratadista, além de pintor; conclusão e retomada das questões levantadas durante o trabalho, de forma a dar síntese do que terá sido o cerne da pesquisa. É importante ressaltar que escolha desse procedimento considera essencial a etapa de observar o quadro enquanto um objeto que, através de sua própria linguagem, fala por si mesmo.

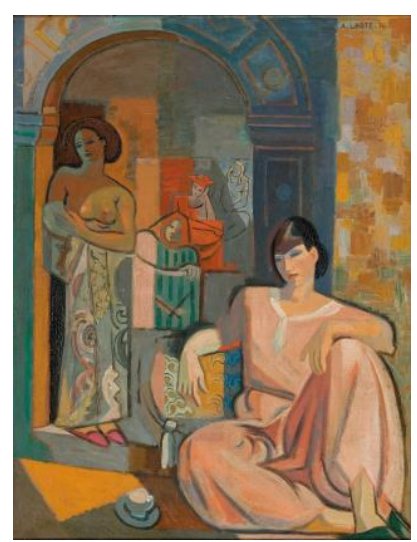

Figura 1. André Lhote (Bordéus, França, 1885 - Paris, França, 1962), Composição - Interior com figuras femininas, 1936. Óleo sobre tela, $17 \times 89,5 \mathrm{~cm}$. Doação Diários Associados, 1947. Inv. MASP.00154. Coleção Museu de Arte de São Paulo Assis Chateaubriand. Foto de João Musa.

\section{Conclusões}

A conclusão parcial atingida até o percurso atual da pesquisa diz respeito à rediscussão da noção de cubismo como um conceito hermético e restrito, de forma que a classificação da obra de acordo com princípios de alguma teoria específica e excludente mostrou-se inviável.

\section{Agradecimentos}

Agradeço ao Fundo de Apoio ao Ensino, à Pesquisa e à Extensão (FAEPEX - UNICAMP) pela bolsa concedida e ao meu orientador, Prof. Dr. Gabriel Ferreira Zacarias.

\footnotetext{
1 BIENAL DO MERCOSUL, 2. Picasso: cubismo e América Latina. Porto Alegre: FBAVM, 1999.

${ }^{2}$ COTTINGTON, David. Cubismo. Lisboa: Editorial Presença, 2000

3 GOLDING, John. Cubism: a history and an analysis, 1907-1914. Cambridge: Belknap, 1988.

${ }^{4}$ GREEN, Christopher. Cubism and its enemies: modern movements and reaction in French art, 1916-1928. New Heaven; London: Yale University Press, 1978, c1977.

${ }^{5}$ LHOTE, André. A. Lhote: rétrospective. Lyon: Musée de Lyon, 1966.

6 ROSENBLUM, Robert. Cubism and twentieth-century art. New York: Abrams, 1982.
} 